\title{
Sustainability transitions in the making: A closer look at actors, strategies and resources
}

\author{
Jacco Farla ${ }^{\mathrm{a}, *}$, Jochen Markard ${ }^{\mathrm{b}}$, Rob Raven ${ }^{\mathrm{c}}$, Lars Coenen ${ }^{\mathrm{d}, \mathrm{e}}$ \\ ${ }^{a}$ Copernicus Institute of Sustainable Development, Utrecht University, Heidelberglaan 2, NL-3584 CS Utrecht, The Netherlands \\ ${ }^{\mathrm{b}}$ Cirus - Innovation Research in Utility Sectors, Eawag - Swiss Federal Institute for Aquatic Science and Technology, Ueberlandstrasse 133, \\ CH-8600 Dübendorf Switzerland \\ c Eindhoven University of Technology, School of Innovation Sciences, Den Dolech 2, NL-5600 MB, Eindhoven, The Netherlands \\ d CIRCLE, Center for Innovation, Research and Competence in the Learning Economy, Lund University, Sölvegatan 16, S-22100 Lund, Sweden \\ e NIFU, Nordic Institute for Studies in Innovation, Research and Education, Wergelandsveien 7, N-0167 Oslo, Norway
}

\section{Introduction}

Modern societies face fundamental sustainability problems in several domains, such as energy, transportation and food. 'Technological fixes' have often provided only temporary and partial solutions due to negative externalities, rebound effects or other unintended consequences (see e.g. $[1,2]$ ). In fact, some solutions reinforced technological and institutional lock-in, thus strengthening existing systems [3]. It has therefore been suggested that societies need to fundamentally restructure systems of consumption and production by initiating so-called sustainability transitions $[1,4,5]$. Whereas it is known that such transformation processes are sluggish and unfold over many decades, the nature of sustainability problems requires imminent action. This tension is further aggravated by citizens' short-term focus and firms' need to secure short-term survival, which makes it difficult for policymakers to implement ambitious sustainability programs [6]. Resolving these problems is critical in addressing the sustainability challenges of the 21st century.

Over the last decade a research community has developed around these topics, which can be short-handed as 'the field of sustainability transitions research'. The field has matured through the establishment of the Sustainability Transitions Research Network (STRN ${ }^{1}$ ), a dedicated journal 'Environmental Innovations and Societal Transitions' and a series of international conferences in Amsterdam (2009), Lund (2011) and Copenhagen (2012, forthcoming). There is a rapidly increasing body of literature, which also includes a number of special issues on topics such as transitions in infrastructure systems [7-9], the multi-level perspective [10], governance and policy issues [11,12], sustainability transitions in Asia [4,13] and the role of spaces and places of sustainability transitions [14]. See Markard et al. [15] for a review of how the field has evolved and what the key journals and topics are.

The emerging field is characterized by a wide variety of topics, approaches and methodologies [15], but a general feature is that transitions towards sustainability are framed from a systems perspective. This is consistent with the general understanding of socio-technical transitions, which are conceptualized as major changes in technological, organizational and institutional terms for both production and consumption (e.g. [16]). Socio-technical transitions involve a broad range of actors and typically unfold over considerable time-spans (e.g. 25 years and above). In the course of such a transition (radically) new products, services, business models and organizations emerge, partly complementing, partly substituting existing ones. Historical examples of socio-technical transitions include the introduction of pipe based water supply [17], the shift from cesspools to sewer systems [18] or the introduction of the automobile and related infrastructure [19,20].

Empirical and theoretical research in the field has led to the development of various conceptual frameworks to understand the dynamics of transitions and to develop tools for policymakers on how to support and guide such transformation processes. Applications of the 'multi-level perspective' have shown under what conditions socio-technical transitions unfolded in the past [21-24] and the 'transition management' approach has made substantial contributions in questions related to the governance

\footnotetext{
* Corresponding author at: Utrecht University, Copernicus Institute of Sustainable Development, PO Box 80115, NL-3508 TC Utrecht, The Netherlands. Tel.: + 31 30 253 7850; fax: + 31302532746 .

E-mail addresses: j.c.m.farla@uu.nl (J. Farla), Jochen.Markard@eawag.ch (J. Markard), R.P.J.M.Raven@tue.nl (R. Raven), Lars.Coenen@circle.lu.se (L. Coenen).

1 See www.transitionsnetwork.org.
} 
of large-scale societal transformations [25-28]. Another important inroad to conceptualizing and studying far-reaching innovations is based on the (technological) 'innovation systems' approach [29-32], which is concerned with analyzing and improving the conditions for the development of novel technologies. Recently, authors have also started to explore the potential of combining the innovation systems concept and the multi-level perspective to better reap the benefits of these complementary approaches [33]. Finally, for readers with a particular interest in prospective technology studies it is worthwhile noting that the long-term orientation and prospective nature of transition processes also constitutes an immediate link to various conceptual frameworks in the field of technology foresight and futures analysis [34-37].

Many of the aforementioned concepts and empirical studies have emphasized the systemic and interrelated nature of innovation processes and socio-technical transitions at the macro or systems level. These insights have been very helpful in sketching the bigger picture, but might have come at the expense of a more actor-oriented and agency-sensitive analysis. The multi-level perspective, for example, has been criticized for a weak conceptualization of agency issues and not paying enough attention to conflicting interests and politics in transition processes [21,28]. This has already triggered some debate, including a clarification of the underlying ontological models of actor behavior [38]. Furthermore, niche based approaches have been challenged for putting too much emphasis on planned, well ordered and consensual management processes ([39]; see [40] for a response). In a similar vein, it has been suggested that the technological innovation systems approach can benefit from a more explicit conceptualization of actor strategies and resources in innovation and transformation processes [41,42].

It is against this background that this special issue draws attention to the dynamic interaction between what different kinds of actors do and what can be observed at the system level. It aims to provide a closer look at how strategies, resources and capabilities of individuals, firms and other organizations impact the overall system and trigger transformation processes, and how these changes at the system level feed-back into the observed strategies at the actor level. This is important, not in the least because the particularity of sustainability transitions is that they are often purposefully initiated (or supported) and directed in the sense that long-term future visions are supposed to guide these transitions [43]. While guidance of distributed actors is essential, it has been acknowledged that future visions as well as the means to achieve these visions are contested [44,45], with different actor groups claiming and advocating different interests. As we improve our understanding of the dynamic interplay of different actors involved in innovation and transition processes, we will be able to untangle some of the complexities of transitions unfolding at the system level.

To contribute to this general line of reasoning, our special issue calls particular attention to the strategies and resources of actors in sustainability transitions. In this introduction we will concentrate on the following questions knowing that these can only shed light on some of the complex issues at hand:

- What strategies do actors adopt to shape sustainability transitions and what resources do they mobilize and deploy in the realization of these strategies?

- What kinds of different actors play a role in these transformation processes and how can and do they align their strategies (and resources) to achieve common goals?

During the 2010 Conference of the European Society of the Study of Science and Technology (EASST, 1-4 September, Trento, Italy) 26 papers were presented within the thematic track "System Innovations and Transitions to Sustainability". From these papers, we selected 7 studies that zoom in on actor strategies and resources in transition processes and thus address the questions raised above. In the following, we give a short summary of each of the papers in the special issue. An overview of distinctive elements in these papers is provided in the section thereafter and in Table 1.

\section{Introducing the papers in this special issue: a closer look at actors, resources and strategies}

In the first paper, Caetano Penna and Frank Geels ([46], this issue) analyze in a longitudinal study how the American car industry has dealt with public concerns about air pollution. It highlights the roles of social movements and civil society actors trying to establish air pollution as a critical issue on the political agenda in opposition to actors from the car industry who downplayed the issue or presented incremental adaptations. The authors develop and test a new 'dialectic issue life cycle' model that includes stylized processes on how (sustainability) issues emerge and possibly lead to fundamental changes in established industries. One of the conceptual conclusions is that issue cycles alone cannot explain the complex dynamics that can be observed in the transformation of established industries. Instead, developments in broader contexts need to be taken into account as well. Penna and Geels further discuss the implications of their findings for sustainability transitions in the car industry, and speculatively suggest that this process is currently in the third phase of their conceptual model.

Tjerk Jan Schuitmaker ([47], this issue) introduces a framework for the analysis of the phenomenon of persistent problems. While many researchers in the field use persistent problems to justify system innovation, the concept 'persistent problem' itself is not extensively theorized. Schuitmaker conceptualizes persistent problems as systemically reproduced negative side effects of success factors of the system in focus. Next, he describes the (re)production of persistent problems in a case from health-care: a new practice for patients with medically unexplained physical symptoms (MUPS). Although health-care cases are less common in the literature on sustainability transitions, the paper clearly illustrates a possible problem for actors in sustainability transitions: in order to change a part of the system they have to adhere to certain other structural parts of the same system. In this case, medical specialists use their status in an academic/clinical context to deviate from certain rules and standards in order to start an interdisciplinary treatment for patients with MUPS. When the actors want to institutionalize their initially successful experiment, they draw on established standards and symbolic capital. This turns out to be an unsuccessful strategy. Schuitmaker shows in 
Table 1

Overview of the papers in this special issue.

\begin{tabular}{|c|c|c|c|c|c|c|}
\hline Paper & $\begin{array}{l}\text { System and } \\
\text { setting }\end{array}$ & $\begin{array}{l}\text { Sustainability } \\
\text { challenge }\end{array}$ & $\begin{array}{l}\text { Actor(s) in } \\
\text { focus }\end{array}$ & Strategies & Resources & $\begin{array}{l}\text { Lesson from an actor- } \\
\text { oriented perspective }\end{array}$ \\
\hline $\begin{array}{l}\text { Penna and } \\
\text { Geels [46] }\end{array}$ & $\begin{array}{l}\text { Automotive } \\
\text { industry; societal } \\
\text { pressure to } \\
\text { change an } \\
\text { existing field; US }\end{array}$ & $\begin{array}{l}\text { Reducing car } \\
\text { emissions to } \\
\text { get cleaner } \\
\text { air }\end{array}$ & $\begin{array}{l}\text { Firms (car } \\
\text { industry), } \\
\text { associations } \\
\text { (social } \\
\text { movement } \\
\text { actors), } \\
\text { individuals } \\
\text { (civil society), } \\
\text { policymakers }\end{array}$ & $\begin{array}{l}\text { Firm strategies with different targets: } \\
\text { a) economic positioning, } \\
\text { b) innovation and technology } \\
\text { development, } \\
\text { c) political context, } \\
\text { d) socio-cultural context }\end{array}$ & $\begin{array}{l}\text { Example: Political } \\
\text { contacts and financial } \\
\text { means were used to } \\
\text { support broad info } \\
\text { campaigns. }\end{array}$ & $\begin{array}{l}\text { Social movement } \\
\text { actors struggle with } \\
\text { incumbents in their } \\
\text { quest to mobilize the } \\
\text { general public and } \\
\text { policymakers. }\end{array}$ \\
\hline $\begin{array}{l}\text { Schuitmaker } \\
\text { [47] }\end{array}$ & $\begin{array}{l}\text { Health-care; } \\
\text { introduction of a } \\
\text { new practice in } \\
\text { an existing field; } \\
\text { The Netherlands }\end{array}$ & $\begin{array}{l}\text { Effective } \\
\text { treatment for } \\
\text { patients with } \\
\text { medically } \\
\text { unexplained } \\
\text { physical } \\
\text { symptoms }\end{array}$ & $\begin{array}{l}\text { Individuals } \\
\text { (Health-care } \\
\text { professionals) }\end{array}$ & $\begin{array}{l}\text { The actors deviate from some of the } \\
\text { existing rules and structures to } \\
\text { address the problem, although they } \\
\text { strongly depend on these structures. }\end{array}$ & $\begin{array}{l}\text { Actors use their status } \\
\text { in an academic/clinical } \\
\text { context and the } \\
\text { discretion of their } \\
\text { position to deviate } \\
\text { from the rules. Still, } \\
\text { they draw on } \\
\text { established standards } \\
\text { and symbolic capital. }\end{array}$ & $\begin{array}{l}\text { By drawing on the } \\
\text { system's structural } \\
\text { elements, actors may } \\
\text { inadvertently fortify } \\
\text { (part of) the existing } \\
\text { system, thus } \\
\text { contributing to the } \\
\text { persistence of } \\
\text { problems. }\end{array}$ \\
\hline $\begin{array}{l}\text { Musiolik } \\
\text { et al. [48] }\end{array}$ & $\begin{array}{l}\text { Energy supply; } \\
\text { clean technology } \\
\text { development; } \\
\text { Germany }\end{array}$ & $\begin{array}{l}\text { Introduce } \\
\text { highly } \\
\text { efficient } \\
\text { domestic } \\
\text { energy } \\
\text { supply; } \\
\text { stationary } \\
\text { fuel cells }\end{array}$ & $\begin{array}{l}\text { Firms (fuel cell } \\
\text { developers), } \\
\text { associations } \\
\text { (formal } \\
\text { networks, } \\
\text { industry } \\
\text { associations), } \\
\text { policymakers }\end{array}$ & $\begin{array}{l}\text { Actors join forces to build up } \\
\text { supportive institutional structures for } \\
\text { a novel technology. Two types of } \\
\text { networking strategies: a) limited and } \\
\text { piecemeal scope, b) complex and } \\
\text { pervasive scope }\end{array}$ & $\begin{array}{l}\text { Two types of } \\
\text { resources: a) } \\
\text { resources of network } \\
\text { members: finances, } \\
\text { knowledge, contacts, } \\
\text { b) network resources: } \\
\text { governance structure, } \\
\text { network reputation, } \\
\text { trust among members }\end{array}$ & $\begin{array}{l}\text { The strategic build-up } \\
\text { of resources at the or- } \\
\text { ganizational, network } \\
\text { and system level is key } \\
\text { for innovation and } \\
\text { transition processes. }\end{array}$ \\
\hline $\begin{array}{l}\text { Quitzao } \\
\text { et al. [49] }\end{array}$ & $\begin{array}{l}\text { Built } \\
\text { environment; } \\
\text { introduction of } \\
\text { new, energy- } \\
\text { efficient technol- } \\
\text { ogies and prac- } \\
\text { tices in spatial } \\
\text { planning; Egedal, } \\
\text { Denmark }\end{array}$ & $\begin{array}{l}\text { Reduce } \\
\text { energy use in } \\
\text { the built } \\
\text { environment; } \\
\text { inclusion of } \\
\text { sustainability } \\
\text { criteria in } \\
\text { spatial } \\
\text { planning }\end{array}$ & $\begin{array}{l}\text { Policymakers } \\
\text { and } \\
\text { administration } \\
\text { (local } \\
\text { municipality) }\end{array}$ & $\begin{array}{l}\text { Policymakers use transformative } \\
\text { spatial planning to: } \\
\text { a) support adoption of } \\
\text { new technologies, } \\
\text { b) push mainstream building firms } \\
\text { to adopt sustainable practices }\end{array}$ & $\begin{array}{l}\text { Use of structural and } \\
\text { relational resources } \\
\text { like associative } \\
\text { network governance, } \\
\text { proximate relations, } \\
\text { dialogue and trust } \\
\text { (-building) }\end{array}$ & $\begin{array}{l}\text { Policymakers can play } \\
\text { a very active and } \\
\text { creative role in } \\
\text { transition processes. }\end{array}$ \\
\hline $\begin{array}{l}\text { Bakker et al. } \\
{[50]}\end{array}$ & $\begin{array}{l}\text { Automotive } \\
\text { industry; clean } \\
\text { technology } \\
\text { development; US }\end{array}$ & $\begin{array}{l}\text { How to } \\
\text { promote and } \\
\text { select } \\
\text { (hydrogen) } \\
\text { technologies } \\
\text { based on } \\
\text { their future } \\
\text { promises }\end{array}$ & $\begin{array}{l}\text { Individuals } \\
\text { (experts, firm } \\
\text { representatives } \\
\text { and } \\
\text { government } \\
\text { representatives) } \\
\text { and committees }\end{array}$ & $\begin{array}{l}\text { Construction of credible expectations } \\
\text { by showing: } \\
\text { a) past development and actual level } \\
\text { of performance, } \\
\text { b) a convincing path forward and } \\
\text { c) a future performance target }\end{array}$ & $\begin{array}{l}\text { The credibility of the } \\
\text { expectations produced } \\
\text { can be seen as a } \\
\text { resource that may lead } \\
\text { to R\&D funding, which } \\
\text { again is a resource for } \\
\text { technology } \\
\text { development }\end{array}$ & $\begin{array}{l}\text { Credible expectations } \\
\text { are essential for novel } \\
\text { technologies, which is } \\
\text { why actors have to } \\
\text { strategically engage in } \\
\text { 'expectations work'. }\end{array}$ \\
\hline $\begin{array}{l}\text { Budde et al. } \\
\text { [51] }\end{array}$ & $\begin{array}{l}\text { Automotive } \\
\text { industry; } \\
\text { strategic choice } \\
\text { of innovation } \\
\text { trajectories in an } \\
\text { existing field; } \\
\text { Germany }\end{array}$ & $\begin{array}{l}\text { Developing } \\
\text { and } \\
\text { supporting } \\
\text { clean } \\
\text { propulsion; } \\
\text { hydrogen } \\
\text { vehicles }\end{array}$ & $\begin{array}{l}\text { Firms (car } \\
\text { manufacturers), } \\
\text { policymakers }\end{array}$ & $\begin{array}{l}\text { Automotive firms: (dis-) engaging in } \\
\text { innovation activities, Government: } \\
\text { (dis-) engaging in supporting a } \\
\text { specific technology }\end{array}$ & $\begin{array}{l}\text { Expectations related to } \\
\text { different levels; } \\
\text { changing expectations } \\
\text { induce change in } \\
\text { strategies }\end{array}$ & $\begin{array}{l}\text { Changing expectations } \\
\text { lead to changing actor } \\
\text { strategies, which } \\
\text { eventually influence } \\
\text { the dynamics of the } \\
\text { transition process. }\end{array}$ \\
\hline $\begin{array}{l}\text { Konrad et al. } \\
{[52]}\end{array}$ & $\begin{array}{l}\text { Domestic energy } \\
\text { supply; clean } \\
\text { technology } \\
\text { development; } \\
\text { hype-and- } \\
\text { disappointment } \\
\text { cycle; Germany, } \\
\text { Switzerland, } \\
\text { Austria }\end{array}$ & $\begin{array}{l}\text { Introduce } \\
\text { highly } \\
\text { efficient } \\
\text { domestic } \\
\text { energy } \\
\text { supply; } \\
\text { stationary } \\
\text { fuel cells }\end{array}$ & $\begin{array}{l}\text { Firms (fuel cell } \\
\text { manufacturers, } \\
\text { utilities) and } \\
\text { research } \\
\text { institutes }\end{array}$ & $\begin{array}{l}\text { Actors pursue different innovation } \\
\text { strategies (lead, follow) and also } \\
\text { strategically influence the discourse } \\
\text { related to the novel technology. }\end{array}$ & $\begin{array}{l}\text { Organizational } \\
\text { resources are one } \\
\text { factor that influences } \\
\text { the sensitivity of actors } \\
\text { to hype- } \\
\text { disappointment } \\
\text { dynamics. }\end{array}$ & $\begin{array}{l}\text { Actors which are less } \\
\text { sensitive to hypes and } \\
\text { disappointment might } \\
\text { constitute the } \\
\text { backbone of a novel } \\
\text { technological field } \\
\text { when expectations } \\
\text { change or collapse. }\end{array}$ \\
\hline
\end{tabular}


his paper that actors who try to change part of the problems in a system, often unintentionally strengthen systemic aspects that cause (other) persistent problems.

The paper by Jörg Musiolik, Jochen Markard and Marko Hekkert ([48], this issue) explores how actors collaborate and join their resources in formal networks to shape the broader innovation system they are operating in. The analysis shows that formal networks differ in their ability to build technological innovation systems around emergent, green technologies. Empirically the study is based on networks related to stationary fuel cell technology in Germany. The paper contributes to technological innovation systems literature by looking more closely at the organizational resources that underpin innovation system dynamics. To do so, the authors investigate how organizational resources give rise to network resources, which in turn, provide system resources. Based on the empirical analysis, the paper suggests two types of formal networks: (1) those that draw primarily on the organizational resources of network members and (2) those that extensively develop and use shared network resources. The paper shows that both types of resources are necessary to achieve the goals of the network, but that the latter tend to offer a higher degree of influence and flexibility in terms of system building. More broadly, the paper points to the importance of studying the specificities in the strategic formation of (technological) innovation systems.

The paper by Maj-Britt Quitzau, Birgitte Hoffmann and Morton Elle ([49], this issue) explores actor strategies in relation to spatial planning and how such strategies can contribute to niche development in the context of a transition towards energyefficient buildings. More specifically it investigates how local planning authorities in the municipality of Egedal have strategically employed spatial planning as an instrument to develop the largest settlement of highly energy-efficient buildings in Denmark, and in doing so, created and nurtured a niche for relevant building technologies. To conduct this analysis, the paper applies a theoretical concept that combines strategic niche management and strategic spatial planning, i.e. local niche planning. The paper discusses the transformative capacity that such niche planning can have at the local level not only to challenge and change mainstream building practices but also to change existing spatial planning frameworks and practices. The paper thus goes well beyond the often rather narrow focus on technology development processes in the support of sustainable niches. As such the paper draws attention to broader, complementary institutional change to support strategic niche management, which assumes more strategic forms of planning than is often practiced today.

The paper by Sjoerd Bakker, Harro van Lente and Marius Meeus ([50], this issue) deals with expectations and the role they play in processes of the technology selection, or even the choice for specific technological transition paths. In their analysis of the US research funding for hydrogen automobiles, the authors show that the support an innovative and potentially path-breaking technology receives, depends on the credibility of the expectations related to the innovation. This credibility again, is subject to the technology's actual level of performance, a convincing path forward and a future performance target, which fits well into broader societal needs and expectations. The paper also shows how expectations and their credibility are carefully created and (re-) assessed by technology proponents. At the same time, prevailing expectations constrain the room for maneuvering that actors have in their quest to foster a particular innovation. With this, the article points to the dynamic interplay of actor strategies (shaping credible expectations) and emergent systemic effects (institutionalization of the new field through collective expectations).

Björn Budde, Matthias Weber and Floortje Alkemade ([51], this issue) show how expectations guide actor strategies in the field of fuel cell and hydrogen vehicles. Expectations and visions are known to be important resources in the guidance of sustainability transitions, and can also be linked to actor strategies. However, it is less clear why actors involved in transition activities appear to change their strategies frequently and suddenly. The paper by Budde and colleagues shows that the changes in actor strategies can be explained by the rather volatile expectations related to different levels. The study shows that car manufacturers refer strongly to expectations about the future regime, while policymakers react more strongly to (changes in) expectations about the socio-technical landscape level.

Kornelia Konrad, Jochen Markard, Annette Ruef and Bernhard Truffer ([52], this issue) deepen our understanding of how organizations in a technological innovation system contribute and respond to hype-and-disappointment cycles at the systems level. A key-notion in their work is 'collective expectations', which are expectations that are acknowledged by a broad range of actors in the field. We know from the sociology of expectations literature that expectations are a critical resource in innovation processes, and that ups-and-downs in collective expectations can have a major impact on the direction and speed of innovation. Konrad and colleagues make an important contribution by investigating how organizations such as firms and research institutes respond but also contribute to such ups-and-downs through their discourse and innovation activities. They make use of the literature on the resource-based view of the firm to explain how and why different organizations in the field of fuel cell technologies in Germany reacted to and enacted a recent hype-and-disappointment cycle. The authors also discuss how the strategic actions of the various actors observed add up and partly re-inforce each other thus resulting in particular dynamics at the system level.

\section{Key findings}

In Table 1 we compare the papers in this special issue, i.e. the topics they address, the actor-related aspects they highlight as well as some of their findings. Below we will take a closer look at the various actors that were studied, the strategies observed and the role different kinds of resources played in the pursuit of strategies towards sustainable innovation and transitions. Actors include different types of organizations such as firms, public authorities (policymakers), associations (industry as well as social movements) and research institutes. Apart from organizations, individuals show up as actors in transition processes - as 'independent' players or as members of an organization (e.g. firm owners, employees). The key characteristic we ascribe to actors is that they can pursue strategies. They have leeway in their decision-making, yet they are also constrained (but not fully determined) by the institutional structures they are embedded in. Strategies refer to the goals actors want to achieve as well as to the activities they pursue and the 
resources they deploy to achieve these goals. Resources can be tangible (e.g. equipment, machinery, finance, human resources) as well as intangible. Intangible resources include assets such as technological know-how, the status or reputation of an actor, its social contacts and network ties. Moreover, resources are conceptualized to be controlled not only by organizations but also by entire industries [53] or emerging technological fields [48].

\subsection{Actors}

Several different types of actors have been analyzed in the studies collected for this special issue. Policymakers and public authorities have a central and traditional role in financing the pre-competitive phase of innovative, more sustainable technologies [48-50], but also showed up in a novel role where they pro-actively created a niche through institutional work that enables experimentation with more sustainable building practices [49]. At the same time, Penna and Geels [46] remind us that, in the past, sustainability issues were less high on the agenda and policymakers had to be pushed by social movements to enforce more demanding legislation. This shows that policymakers tend to be constrained by relationships with wider publics and industry actors, following and reacting to the outcomes of the societal debate.

Also firms are described in a broad range of different roles. Sometimes they actively engage in (radical) innovation trajectories [48,51,52], and help building a supportive environment or innovation system [48]. In other words, firms deliberately create positive externalities and invite others to join an emerging field to gain momentum against established technologies and competing innovations. These findings show that firm strategies can be far-reaching and long-term oriented (hence relevant for sustainability transitions). An example of such strategic maneuvering is the 'expectations work', which firms pursue in interaction with other actors to strengthen emerging clean technologies [48,50,52]. The paper by Penna and Geels [46] illustrates a different role and shows how incumbent firms can be less driven by their own innovation agenda but only reluctantly engage in a 'green' innovation agenda in response to pressures exerted by social movement actors and policymakers.

Other important actors in sustainability transitions as described in the papers are social movements, civil society and consumers [46], experts and research organizations [48,50,52] and individual actors that try to change a system from within [47]. An important issue to keep in mind here is that in all studies actors engaged and interacted with other types of actors. It was never just a single (type of) actor involved in the transformation processes observed, although some cases $[47,49]$ were characterized by a few very prominent actors. The former might seem obvious given the systemic nature of socio-technical transitions. However, we have to keep in mind that some of the existing literature uses concepts like prime movers [54], system builders [55] or change agents [56] that rather highlight the transformative role of prominent single actors (organizations but also individuals) than the importance of larger actor networks and collective action.

\subsection{Strategies and resources}

The strategies of the actors studied in the seven papers are directed at different targets, including other actors in the system (e.g. policymakers $[46,48,50]$, firms $[48,49,52]$ or the broader public [46]), institutional structures (e.g. standards, regulations and guidelines [45-47,49], collective expectations [48,51,52]) or new organizational structures in the form of formal networks and associations [48]. Due to this broad variety of targets, also the variety of strategies is large. However, a commonality of the observed strategies is that they all reach out to the broader environment (or system) the actors are part of. In all cases, the actors tried to achieve more or less far-reaching changes of existing structures or practices - or tried to prevent exactly such changes [46]. This observation supports the rationale for this special issue that a closer look at strategies and actor resources improves our understanding of how structural changes of socio-technical systems come about.

Another strategy dimension is whether actors pursue their goals alone or join forces with others. Because of the complexity of the sustainability problems addressed in the papers and the intention to initiate fundamental changes, we would expect the studies to report (attempts to) a high degree of coordination between actors in the development and implementation of their strategies. Interestingly enough though, collective action was only observed in some of the papers [48-50,52]. While this might be due to analytical choices in the design of the studies, it is certainly an issue that deserves further attention in future research.

In the various strategies, different kinds of resources played a key role. While individual and organizational resources (e.g. knowledge, status, political contacts, financial means) were certainly crucial in most cases, the findings also show that the institutional structures of existing or emerging socio-technical systems may constitute valuable resources, which the actors use to develop and implement their strategies. For example, Penna and Geels [46] describe four types of deep structural elements of an 'industry regime': 1) capabilities and technical knowledge, 2) identity and mission, 3) beliefs and cognitive frames and 4) regulations and other formal policies. Firms draw on these structural, tangible and intangible elements and at the same time, they try to change (some of) them. Schuitmaker [47] shows that changing these broader institutional structures is very difficult exactly because they represent valuable resources for those actors that benefit from the existing system. Institutional change then becomes an issue of conflicting interests and power struggles. As a consequence, actors that pursue systemic change in order to initiate a sustainability transition, find themselves in a hostile environment. They need to build up supportive structures to make change possible. In this special issue, we see two routes to build such supportive structures: associating with other actors in formal and informal networks, and (strategically) engaging in 'expectations work'. Obviously, both routes can also be combined.

Musiolik et al. [48] track how innovating actors deliberately create or modify institutional structures (system resources) in order to build-up a supportive environment (innovation system) for an emerging technology. Firms and other actors combine their organizational resources (finance, knowledge, reputation) by using formal networks, some of which even accumulate and 
control specific network resources. Both organizational and network resources are then deployed towards institutional change. The case described by Quitzao et al. [49] not only is quite different, but also describes the deliberate creation and modification of institutional and organizational structures. Public authorities are the initiators that draw on structural and relational resources like associative network governance, proximate relations and trust to set goals that partly change the system for the building firms involved.

Expectations can also be regarded as specific resources created by collective action. Bakker et al. [50] for instance argue that collective expectations are held by many actors, and therefore fulfill a structuring role in innovation processes. An actor can draw on these expectations as a legitimation for his or her own work, where another actor cannot ignore the forceful (credible) expectations and needs to join in on development activities [57]. Expectations as structuring features can be volatile [58]. If they are not deeply embedded in the system, the structuring effect can suddenly disappear when actors start to draw on competing expectations. Budde et al. [51] show how sudden changes in actor strategies in technological innovation can be a result from changes in such collective expectations. Konrad et al. [52] also observe that different actors are more or less sensitive to such changes in expectations. Furthermore, they highlight that actors strategically influence such expectations ('expectations work') through their discourse activities and thus play an active role in expectation dynamics. Finally, the authors [52] suggest that actors which are less sensitive to the ups and downs of expectations can become the backbone of a novel technological field because they largely maintain their position and innovation activities.

In summary, the seven contributions to this special issue have shown how the strategic work of different actors contributes to a variety of changes in the broader institutional environment, or system. In turn, it was reported how (the resulting) system level dynamics affect the actor strategies. Given the large diversity of strategies and resources that were deployed to address sustainability challenges, we cannot give definitive answers to the questions that we posed in our introduction. One way forward for future research would be to sort out certain types of sustainability transition challenges and to identify strategies and conditions under which they can be addressed. With the current set of papers, we made a first step along this way, showing that a more actor-oriented and agency-sensitive approach generates a broad set of interesting findings, which are important to better understand what actors can (and cannot) achieve in sustainability transition processes.

\section{Outlook}

The seven contributions showed that changes in socio-technical systems (established sectors as well as emerging fields) can often be traced back to strategic interventions of particular actors. Innovation and transition processes, in other words, do not just emerge from a rather unintentional interplay of actors that pursue their own narrow strategies. Instead, they may be strategically shaped by players with some kind of a 'larger plan' or vision - at least to a certain extent. Future research may embark in a more systematic way on how actor strategies and resources impact the outcome of sustainability transitions at the system level.

The 'system-building' strategies that we see in this special issue depend on the resources that are available for each specific actor at the individual or organizational level, but also at the level of the socio-technical system (e.g. technology reputation, collective expectations, symbolic capital). While on first sight, these resources can be interpreted as factors that enable strategic action, they also represent constraints for what actors can achieve. This dual nature is best covered with the concept of institutional structures that enable and constrain action [59]. One of the theoretical conclusions here is that our actor-oriented approach to sustainability transitions has significant overlap with the broader field of research on institutional entrepreneurship [60,61] and institutional work [62]. In fact, Schuitmaker [47] shows that actors may unintentionally fortify the institutional structures they are trying to change. This relates to the long-standing 'paradox of embedded agency' [61], i.e. the challenge of how actors can change the institutional and systemic conditions that are enabling and constraining their very actions in the present. While an institutional perspective would emphasize the broader systemic mechanisms at play, an actor-oriented approach can provide complementary insights from an organizational perspective. Further research may thus try to uncover how much leeway actors really have in pursuing sustainability transitions within an existing system. Because joining forces between actors can be important to that end, it is also promising to address the issue of collective action, both in terms of how actors collaborate and coordinate their actions in 'making transitions' as well as the role of competition and conflicts therein.

Another aspect for future research is the large number and variety of actors involved in even small system changes, not to speak of far-reaching transition processes. From the papers we have seen that policymakers, industry associations, social movements, technology manufacturers and individual professionals have significantly contributed to knowledge development, the change of institutional structures, the dynamics of collective expectations, issue attention, etc. As the transition unfolds, the relationships between these actors, their roles and relative positions may also start to change. One consequence might be that alliances, which in some time have worked well (e.g. towards system stabilization), may break apart while new ones are formed. A related topic here is the distinction between incumbent actors and their networks and newcomers (or entrepreneurs). It is often expected that incumbents are proponents of established socio-technical systems and use their resources accordingly, while newcomers are working in favor of alternative configurations and system transformation. The seven papers in our special issue have not dealt with this distinction and the corresponding roles explicitly, but we see potential to develop this line of research further. If we understand the struggles of actors with competing interests and which kinds of resources they can mobilize in support of their goals, we will better be able to assess the conditions for sustainability transitions to materialize. 


\section{Acknowledgments}

We would like to thank all participants in the 'Systems innovation and Transitions to Sustainability' track of the 2010 EASST conference in Trento. We further thankfully acknowledge the work that many reviewers have put into reviewing earlier versions of the papers in this special issue. We also thank Bernhard Truffer for advice on this introductory paper, and Harold Linstone for providing the opportunity to make this special issue.

\section{References}

[1] J.C.J.M. van den Bergh, B. Truffer, G. Kallis, Environmental innovation and societal transitions: introduction and overview, Environ. Innov. Soc. Transitions 1 (2011) 1-23.

[2] M. Frondel, Guest editorial: energy conservation, the rebound effect, and future energy and transport technologies: an introduction to energy conservation and the rebound effect, Int. J. Energy Technol. Policy 2 (2004) 203-208.

[3] G.C. Unruh, Understanding carbon lock-in, Energy Policy 28 (2000) 817-830.

[4] F. Berkhout, D. Angel, A. Wieczorek, Sustainability transitions in developing Asia: are alternative development pathways likely? Technol. Forecast. Soc. Chang. 76 (2009) 215-217.

[5] J. Grin, J. Rotmans, J. Schot, Transitions to sustainable development. New directions in the study of long term transformative change, Routledge Studies in Sustainability Transitions, Routledge, New York/London, 2010.

[6] H.A. Linstone, Decision making for technology executives: using multiple perspectives to improve performance, Artech House Technology Management and Professional Development Library, Artech house, 1999.

[7] D. Loorbach, N. Frantzeskaki, W. Thissen, Introduction to the special section: infrastructures and transitions, Technol. Forecast. Soc. Chang. 77 (2010) 1195-1202.

[8] R. Haas, J. Watson, W. Eichhammer, Transitions to sustainable energy systems -introduction to the energy policy special issue, Energy Policy 36 (2008) 4009-4011.

[9] A. Schreuer, H. Rohracher, P. Späth, Transforming the energy system: the role of institutions, interests and ideas, Technol. Anal. Strateg. Manage. 22 (2010) 649-652.

[10] A. Smith, J.-P. Voß, J. Grin, Innovation studies and sustainability transitions: the allure of the multi-level perspective and its challenges, Res. Policy 39 (2010) $435-448$.

[11] J.-P. Voß, A. Smith, J. Grin, Designing long-term policy: rethinking transition management, Policy Sci. 42 (2009) $275-302$.

[12] J. Newig, J.-P. voß, J. Monstadt, Editorial: governance for sustainable development in the face of ambivalence, uncertainty and distributed power: an introduction, J. Environ. Policy Plann. 9 (2007) 185-192.

[13] F. Berkhout, G.P.J. Verbong, A. Wieczorek, R. Raven, L. Lebel, X. Bai, Sustainability experiments in Asia: innovations shaping alternative development pathways? Environ. Sci. Policy 13 (2010) 261-271.

[14] L. Coenen, B. Truffer, Places and spaces of sustainability transitions: geographical contributions to an emerging research and policy field, Eur. Plan. Stud. 20 (2012).

[15] J. Markard, R. Raven, B. Truffer, Sustainability transitions: an emerging field of research and its prospects, Res. Policy 41 (2012) $955-967$.

[16] F.W. Geels, J. Schot, The dynamics of sociotechnical transitions-a socio-technical perspective, in: J. Grin, J. Rotmans, J. Schot (Eds.), Transitions to Sustainable Development. New Directions in the Study of Long Term Transformative Change, Routledge, New York/London, 2010.

[17] F.W. Geels, Co-evolution of technology and society: the transition in water supply and personal hygiene in the Netherlands (1850-1930) - a case study in multi-level perspective, Technol. Soc. 27 (2005) 363-397.

[18] F.W. Geels, The hygienic transition from cesspools to sewer systems (1840-1930): the dynamics of regime transformation, Res. Policy 35 (2006) $1069-1082$.

[19] F.W. Geels, The dynamics of transitions in socio-technical systems: a multi-level analysis of the transition pathway from horse-drawn carriages to automobiles (1860-1930), Technol. Anal. Strateg. Manage. 17 (2005) 445-476.

[20] G.P.A. Mom, D.A. Kirsch, Technologies in tension: horses, electric trucks, and the motorization of American cities, 1900-1925, Technol. Cult. 42 (2001) 489-516.

[21] A. Genus, A.-M. Coles, Rethinking the multi-level perspective of technological transitions, Res. Policy 37 (2008) $1436-1445$.

[22] F.W. Geels, Technological transitions as evolutionary reconfiguration processes: a multi-level perspective and a case-study, Res. Policy 31 (2002) 1257-1274.

[23] F.W. Geels, J. Schot, Typology of sociotechnical transition pathways, Res. Policy 36 (2007) 399-417.

[24] R. Kemp, J. Schot, R. Hoogma, Regime shifts to sustainability through processes of niche formation: the approach of strategic niche management, Technol. Anal. Strateg. Manage. 10 (1998) 175-198.

[25] R. Kemp, J. Rotmans, Transition Management: managing the co-evolution of technical, environmental and social systems, in: K.M. Weber, J. Hemmelskamp (Eds.), Towards Environmental Innovation Systems, Springer, Heidelberg, 2005, pp. 33-55.

[26] J. Nill, R. Kemp, Evolutionary approaches for sustainable innovation policies: from niche to paradigm? Res. Policy 38 (2009) $668-680$.

[27] J. Rotmans, R. Kemp, M. Van Asselt, More evolution than revolution: transition management in public policy, Foresight-J. Future Stud. Strateg. Think. Policy 3 (2001) 15-31.

[28] A. Smith, A. Stirling, F. Berkhout, The governance of sustainable socio-technical transitions, Res. Policy 34 (2005) 1491-1510.

[29] A. Bergek, S. Jacobsson, B. Carlsson, S. Lindmark, A. Rickne, Analyzing the functional dynamics of technological innovation systems: a scheme of analysis, Res. Policy 37 (2008) 407-429.

[30] B. Carlsson, R. Stankiewicz, On the nature, function and composition of technological systems, J. Evol. Econ. 1 (1991) 94.

[31] M.P. Hekkert, R.A.A. Suurs, S.O. Negro, S. Kuhlmann, R. Smits, Functions of innovation systems: a new approach for analysing technological change, Technol. Forecast. Soc. Chang. 74 (2007) 413-432.

[32] S. Jacobsson, A. Bergek, Innovation system analyses and sustainability transitions: contributions and suggestions for research, Environ. Innov. Soc. Transitions 1 (2011) 41-57.

[33] J. Markard, B. Truffer, Technological innovation systems and the multi-level perspective: towards an integrated framework, Res. Policy 37 (2008) $596-615$.

[34] B. Truffer, J.P. Voß, K. Konrad, Mapping expectations for system transformations: lessons from sustainability foresight in German utility sectors, Technol. Forecast. Soc. Chang. 75 (2008) 1360-1372.

[35] B. Elzen, F.W. Geels, P.S. Hofman, K. Green, Socio-technical scenarios as a tool for transition policy: an example from the traffic and transport domain, in: B. Elzen, F.W. Geels, K. Green (Eds.), System Innovation and the Transition to Sustainability: Theory, Evidence and Policy, Edward Elgar, Cheltenham, UK, 2004, pp. 251-281.

[36] J. Markard, M. Stadelmann, B. Truffer, Prospective analysis of technological innovation systems: identifying technological and organizational development options for biogas in Switzerland, Res. Policy 38 (2009) 655-667.

[37] A.L. Porter, W.B. Ashton, G. Clar, J.F. Coates, K. Cuhls, S.W. Cunningham, K. Ducatel, P. Van der Duin, L. Georgehiou, T. Gordon, H. Linstone, V. Marchau, G. Massari, I. Miles, M. Mogee, A. Salo, F. Scapolo, R. Smits, W. Thissen, Technology futures analysis: toward integration of the field and new methods, Technol. Forecast. Soc. Chang. 71 (2004) 287-303.

[38] F.W. Geels, The multi-level perspective on sustainability transitions: responses to seven criticisms, Environ. Innov. Soc. Transitions 1 (2011) 24-40.

[39] H. Lovell, The governance of innovation in socio-technical systems: the difficulties of strategic niche management in practice, Sci. Public Policy 34 (2007) 35-44. 
[40] R.P.J.M. Raven, G.P.J. Verbong, W.F. Schilpzand, M.J. Witkamp, Translation mechanisms in socio-technical niches: a case study of Dutch river management, Technol. Anal. Strateg. Manage. 23 (2011) 1063-1078.

[41] J. Musiolik, J. Markard, Creating and shaping innovation systems: formal networks in the innovation system for stationary fuel cells in Germany, Energy Policy 39 (2011) 1909-1922.

[42] J. Markard, B. Truffer, Actor oriented analysis of innovation systems: exploring micro-meso level linkages in the case of stationary fuel cells, Technol. Anal. Strateg. Manage. 20 (2008) 443-464.

[43] F. Berkhout, Normative expectations in systems innovation, Technol. Anal. Strateg. Manage. 18 (2006) 299-311.

[44] M. Eames, W. McDowall, M. Hodson, S. Marvin, Negotiating contested visions and place-specific expectations of the hydrogen economy, Technol. Anal. Strateg. Manage. 18 (2006) 361-374.

[45] K.M. Weber, Transforming large socio-technical systems towards sustainability. On the role of users and future visions for the uptake of city logistics and combined heat and power generation, Innovations 16 (2003) 155-176.

[46] C.C.R. Penna, F.W. Geels, Multi-dimensional struggles in the greening of industry: A dialectic issue lifecycle model and case study, Technological Forecasting and Social Change 79 (2012) 999-1020 (this issue).

[47] T.J. Schuitmaker, Identifying and unravelling persistent problems, Technological Forecasting and Social Change 79 (2012) $1021-1031$ (this issue).

[48] J. Musiolik, J. Markard, M. Hekkert, Networks and network resources in technological innovation systems: towards a conceptual framework for system building, Technological Forecasting and Social Change 79 (2012) 1032-1048 (this issue).

[49] M.-B. Quitzao, B. Hoffman, M. Elle, Local niche planning - and its strategic implications for implementation of energy-efficient technology, Technological Forecasting and Social Change 79 (2012) 1049-1058 (this issue).

[50] S. Bakker, H. Van Lente, M.T.H. Meeus, Credible expectations - the US Department of Energy's Hydrogen Program as enactor and selector of hydrogen technologies, Technological Forecasting and Social Change 79 (2012) 1049-1058 (this issue).

[51] B. Budde, F. Alkemade, M. Weber, Expectations as a key to understanding actor strategies in the field of fuel cell and hydrogen vehicles, Technological Forecasting and Social Change 79 (2012) 1059-1071 (this issue).

[52] K. Konrad, J. Markard, A. Ruef, B. Truffer, Strategic Responses to Fuel Cell Hype \& Disappointment, Technological Forecasting and Social Change 79 (2012) $1084-1098$ (this issue).

[53] N.J. Foss, B. Eriksen, Competitive advantage and industry capabilities, in: C.A. Montgomery (Ed.), Resource-Based and Evolutionary Theories of the Firm: Towards a Synthesis, Kluwer Academic Publishers, Boston, 1995, pp. 43-69.

[54] S. Jacobsson, A. Johnson, The diffusion of renewable energy technology: an analytical framework and key issues for research, Energy Policy 28 (2000) 625-640.

[55] T.P. Hughes, The evolution of large technical systems, in: W.E. Bijker, T.P. Hughes, T.J. Pinch (Eds.), The Social Construction of Technological Systems, The MIT Press, Cambridge, MA, 1987, pp. 51-82.

[56] E.M. Rogers, Diffusion of Innovations, The Free Press, New York, 2003.

[57] H. van Lente, Promising Technology: Dynamics of Expectations in Technological Developments, Twente Unversity, Enschede, 1993.

[58] A. Ruef, J. Markard, What happens after a hype? How changing expectations affected innovation activities in the case of stationary fuel cells, Technol. Anal. Strateg. Manage. 22 (2010) 317-338.

[59] W.R. Scott, Institutions and Organizations: Ideas and Interests, Third ed. Sage publishers, Thousand Oaks, CA, USA, 2008.

[60] R. Garud, C. Hardy, S. Maguire, Institutional entrepreneurship as embedded agency: an introduction to the special issue, Organ. Stud. 28 (2007) 957-969.

[61] J. Battilana, B. Leca, E. Boxenbaum, How actors change institutions: towards a theory of institutional entrepreneurship, Acad. Manage. Ann. 3 (2009) 65-107.

[62] T.B. Lawrence, R. Suddaby, B. Leca, Institutional Work: Actors and Agency in Instutional Studies of Organizations, Cambridge University Press, Cambridge, UK, 2009.

Jacco Farla is an assistant professor at the Department of Innovation, Environmental and Energy Sciences of Utrecht University (The Netherlands). His main research interests are in the field of (system) innovations for sustainable development in the energy and transport sectors.

Jochen Markard works as a group leader and senior researcher at Cirus/Eawag. He received his PhD in 2003 from ETH Zurich with a thesis in the field of innovation studies. His research interests are innovation and transition processes in infrastructure sectors (energy supply, urban water management) with a focus on radical and sustainable technologies.

Rob Raven is an assistant professor at the School of Innovation Sciences of the Eindhoven University of Technology. His research interests are in sustainability transitions with a specific focus on the role of niches and sustainability experiments, both in Europe and Asia. He holds a PhD in transition research (2005) and has previously worked at the Energy research Centre of the Netherlands. Rob is a founding member of the Sustainability Transitions Research Network.

Lars Coenen is an associate professor at CIRCLE (Centre for Innovation, Research and Competence in the Learning Economy) at Lund University, Sweden and a senior researcher at NIFU, Norway. His research interests are at the intersection of economic geography and sustainability transition studies with a focus on how radical and sustainable technologies emerge and diffuse in different territorial contexts and give way to industrial renewal. 